УДК 373.14:004.9

Науменко Ольга Михайлівна

молодший науковий співробітник відділу лабораторних комплексів засобів навчання Інститут інформаційних технологій і засобів навчання НАПН України, м. Київ, Україна o.naumenko@iitta.gov.ua

\title{
МЕТОДИКА ПІДГОТОВКИ ЗАНЯТЬ 3 ВИВЧЕННЯ ХІМІЧНИХ ТЕХНОЛОГІЧНИХ ПРОЦЕСІВ 3 ВИКОРИСТАННЯМ ІНТЕРНЕТ-РЕСУРСІВ
}

\begin{abstract}
Анотація. Розглядаються окремі питання методики підготовки і проведення занять із застосування Інтернет-ресурсів для демонстрації технологічних процесів у вивченні хімії у старшій школі. Вивчення наукових основ сучасного виробництва, у тому числі й хімічних технологічних процесів, $є$ важливим засобом формування в учнів необхідних життєвих компетенцій. Процес вивчення хімічних виробництв пов'язує теорію 3 практикою, конкретизує і поглиблює знання теоретичних основ хімії, а також сприяє профорієнтації учнівської молоді. Значну увагу приділено порадам для вчителів стосовно методики використання засобів інформаційно-комунікаційних технологій під час підготовки і проведення практичних і лабораторних занять, інших форм навчально-пошукової діяльності учнів.
\end{abstract}

Ключові слова: Інтернет; інформатизація освіти; хімія; вивчення хімії; технологічні процеси.

\section{1. ВСТУП}

Сучасні тенденції розвитку педагогічної науки, зокрема, широке застосування Інтернет-орієнтованих освітніх технологій, поступово змінюють усталені підходи і в галузі хімічної освіти. Зрозуміло, що далеко не всі школи мають повністю комп'ютеризовані кабінети хімії, але поступово збільшується кількість кабінетів, які оснащені сучасними мультимедійними засобами, що дозволяють систематично використовувати інформаційно-комунікаційні технології у вивченні хімії. Спеціалізоване програмне забезпечення для електронних дошок дозволяє працювати 3 текстами, аудіо- та відеоматеріалами, Інтернет-ресурсами тощо. Це надає можливість вчителю хімії створювати конспекти уроків, демонстрації, презентації, які, у свою чергу, підвищують рівень сприйняття навчальної інформації й активізують пізнавальну діяльність учнів.

Постановка проблеми. Окрема складова використання засобів IКТ на уроках хімії - це моделювання хімічних процесів, що дозволяє більш раціонально організувати вивчення таких тем, для яких демонстраційний експеримент неможливо провести в умовах шкільної хімічної лабораторії. Демонстрація хімічних дослідів або технологічних процесів 3 використанням Інтернет-ресурсів - це практично єдиний засіб, який дозволяє забезпечити оптимальні умови сприйняття відповідного навчального матеріалу на уроках хімії. Утім, застосування сучасних інформаційних технологій дозволяє вчителю вирішувати низку завдань дидактичного й організаційного характеру, серед яких:

- активізація процесу навчання;

- унаочнення навчального матеріалу;

- розвиток культури розумової діяльності;

- підвищення рівня самостійної діяльності учнів.

Отже, інформатизацію освіти загалом слід розглядати не просто як використання комп'ютера та інших електронних засобів, а як новий підхід до організації навчання на 
основі впровадження інформаційної продукції і педагогічних технологій нового покоління. Наразі важливо не перебільшувати роль засобів IКТ у навчальній діяльності, оскільки передавання інформації не слід ототожнювати 3 передаванням знань i культури, а це, у свою чергу, вимагає й розвитку нових напрямків педагогічної науки.

Сучасні вчителі мають уміти кваліфіковано вибирати і застосовувати саме ті педагогічні технології, які повною мірою відповідають змісту і цілям вивчення конкретної дисципліни, сприяють досягненню цілей гармонійного розвитку учнів 3 урахуванням їх індивідуальних особливостей.

Аналіз останніх досліджень і публікацій. Фахівці у галузі педагогіки та IКТ виділяють декілька основних напрямів у вивченні шкільного курсу хімії, де виправдано використання засобів інформаційно-комп’ ютерної технології.

1. Наочне представлення об'єктів макро- i мікросвіту, особливо таких, які практично неможливо показати в лабораторії хімічного кабінету, але які можуть бути продемонстровані як комп’ютерні моделі. У цьому напрямі доцільно використовувати презентації, де застосовуються анімації, тривимірні динамічні моделі, різні види графічного подання інформації, які можна відшукати в Інтернет-ресурсах навчального характеру.

2. Моделювання хімічних експериментів і хімічних реакцій, що супроводжується показом відеофільмів або слайдів. Наприклад, небезпечні властивості окремих речовин i ïx токсичність не можна продемонструвати в хімічному кабінеті, неможливі лабораторні досліди і практичні роботи 3 вибуховими, горючими, отруйними речовинами, хоча вивчення хімічних властивостей багатьох з них входить в шкільну програму. Реальну допомогу під час розв'язування цих проблем дає використання готових навчальних матеріалів, які можна відшукати в Інтернеті (поради стосовно організації пошуку Інтернет-ресурсів навчального характеру можна знайти у попередніх роботах автора [4-6]).

3. Знайомство з виробництвом хімічних продуктів з використанням комп'ютерних технологій. Наприклад, демонстрація відеофільму надає можливість представити віртуальну модель нафтопереробного заводу, процеси виробництва різноманітних металів, реальний хімічний технологічний процес отримання певних продуктів, коли пояснення теми проводиться викладачем у вигляді лекції з використанням Інтернетресурсів.

4. Тестовий контроль за рівнем навчальних досягнень учнів, який може проводитися під час підготовки до контрольної або самостійної роботи, централізованому тестуванню, науково-пошукових робіт (використовуються ресурси Інтернету).

Використання комп'ютерних технологій на уроках хімії дає можливість здійснювати тренування в процесі засвоєння навчального матеріалу і самостійної роботі учнів, проводити лабораторні роботи в умовах імітації в комп'ютерній програмі реального хімічного процесу [9].

Педагогічною наукою i практикою доведено, що робота 3 персональним комп'ютером і відповідним програмним забезпеченням навчального характеру на уроках хімії і в позаурочний час активізує пізнавальну діяльність, ефективно забезпечує реалізацію індивідуального підходу до навчання, сприяє реалізації міжпредметних зв'язків хімії з іншими предметами природничо-наукового циклу і $з$ іншими циклами навчальних предметів, наприклад, з інформатикою, математикою як метапредметами, 3 циклами гуманітарних предметів, наприклад, хімії з історією, економікою, іноземною мовою та ін. [3].

Метою статті $є$ надання методичних порад учителям стосовно підготовки i проведення занять 3 вивчення хімічних технологічних процесів, оптимізації пошуку 
Інтернет-ресурсів, які можна використовувати для демонстрації технологічних процесів, що вивчаються у курсі хімії. Результати дослідження розраховані на використання вчителями хімії, які не мають поглибленої спеціальної підготовки у галузі інформаційно-комунікаційних технологій i ïx застосування в навчальному процесі, однак володіють комп’ютерними засобами на рівні звичайного користувача.

\section{2. МЕТОДИ ДОСЛІДЖЕННЯ}

Дослідження проводилось у рамках НДР «Модернізація шкільного навчального експерименту на основі Інтернет орієнтованих педагогічних технологій 0112U000280» та індивідуальної теми «Використання Інтернет-ресурсів для демонстрації технологічних процесів в курсі хімії середньої школи».

Під час дослідження використовувались такі методи: аналіз теоретичних джерел 3 проблем інноваційних методик, вивчення й узагальнення досвіду організації застосування інформаційних технологій навчання, Інтернет-пошук.

\section{3. РЕЗУЛЬТАТИ ДОСЛІДЖЕННЯ}

Вивчення у середній школі наукових основ сучасного виробництва, у тому числі й хімічних технологічних процесів, $є$ важливим засобом формування в учнів необхідних життєвих компетенцій. Процес вивчення хімічних виробництв пов'язує теорію 3 практикою, конкретизує і поглиблює знання з теоретичних основ хімії, а також сприяє профорієнтації учнівської молоді [1].

Для формування необхідних життєвих компетенцій не потрібно вивчати з учнями велику кількість хімічних технологічних процесів, адже загальноосвітня підготовка не вимагає навчати потроху всьому, головне - ознайомлення 3 основами хімічної індустрії загалом. Тому на уроках хімії мають вивчатися найбільш важливі і поширені хімічні виробництва, які доступні для розуміння учнів старших класів, а також найтиповіші, що відображають використання хімічних теорій і законів у практичній діяльності людини.

Програмою середньої школи передбачено вивчення окремих хімічних технологічних процесів, зокрема, отримання кислот, виробництво мінеральних добрив i засобів захисту рослин, виробництво металів (чугуна, сталі, алюмінію та інших), переробки нафти, коксування вугілля [8]. У процесі вивчення цієї відносно невеликої кількості виробництв учні мають ознайомитися із загальними основами сучасної хімічної промисловості, наразі головна увага приділяється не стільки технологіям і пов'язаним з ними процесами, скільки хімічній сутності виробничих процесів. При цьому важливо пам'ятати, що загальноосвітня школа не готує хіміків-фахівців, а лише сприяє тому, щоб отримані знання $з$ основ хімії стали складовою свідомого вибору подальшої професійної підготовки.

Вивчення низки технологічних процесів доцільно проводити 3 використанням засобів ІКТ і відповідних Інтернет-ресурсів. Упровадження цих засобів у навчанні хімії дозволяє досить ефективно розв’ язувати такі педагогічні завдання:

- навчати опрацьовувати інформацію, сприймати зміст інформаційних повідомлень;

- розвивати комунікативні здібності;

- формувати вміння знаходити, передавати і приймати потрібну інформацію 3 використанням різноманітних технічних засобів; 
- включати позашкільну інформацію (Інтернет-ресурси) до контексту базової шкільної освіти;

- розвивати критичне мислення, формувати дослідницькі вміння і приймати оптимальні рішення.

До особливостей диференційованого функціонування IКТ в навчанні хімії можна віднести:

- разом із загальнопедагогічними, загальними інформаційно-технологічними цілями розв'язуються конкретні методичні цілі предметного навчання, наприклад реалізація функції керованого в інтерактивному режимі хімічного моделювання i конструювання, розв'язування розрахункових i експериментальних завдань, виявлення на їх основі і графічна фіксація хімічних закономірностей, створення учнівських проектів 3 розв'язання комплексних хіміко-екологічних завдань;

- технологія навчання з використанням засобів ІКТ й Інтернет-ресурсів покликана передусім, поряд із розвитком загальних умінь, формувати системні знання й узагальнені предметні уміння з хімії, застосовувати їх за допомогою комп'ютера до розв'язування різних прикладних завдань (здійснювати модельний експеримент, розв'язувати типові розрахункові й експериментальні завдання, кодувати інформацію в символіко-графічній формі, наочно виражати хімічні закономірності і т. д.);

- інформаційна технологія в навчанні хімії, окрім предметних умінь, формує принципово новий тип умінь - узагальнені комп'ютерно-хімічні уміння, що дозволяють активно використати комп'ютер і його програмно-інструментальні прикладні можливості для розв'язування різноманітних завдань, для учнівського проектування моделей розв'язування певних проблем (у тому числі й екологічного характеру) і орієнтовних дій.

Основні цілі і завдання використання засобів IКТ в навчанні хімії можна розділити на декілька груп.

До першої групи завдань відносяться ті, що пов'язані 3 великим обсягом обчислювальної роботи, наприклад квантово-механічні розрахунки, кінетичний опис складних хімічних реакцій, комп'ютерне планування синтезу, моделювання роботи складних приладів, технологічних процесів і тому подібне.

До другої групи відносяться завдання на побудову графіків, тривимірне зображення молекул, зображення механізмів реакцій і тому подібне. Наприклад, вивчення залежності стану газу від різних чинників.

До третьої групи відносяться завдання моделювання. Хімічна наука побудована на моделях як засобах розуміння і прогнозування. У хімічній освіті моделювання використовують для експериментально важкодоступних систем. Через моделювання формується системно-комбінаторне мислення, уміння розв' язувати реальні завдання.

До четвертої групи завдань відноситься пошук і застосування інформаційнодовідкових і навчальних систем з ресурсів Інтернету, що є джерелами інформації для самостійного вивчення матеріалу.

П'ята група розглядає завдання практичного характеру - тренажери, призначені для формування і закріплення умінь і навичок, а також для самопідготовки учнів. До цієї групи також відносять програмні засоби, що дозволяють контролювати рівень навчальних досягнень учнів, проведення попереднього контролю готовності учнів до лабораторних робіт, передлабораторне моделювання, обробка даних експерименту, побудова графічних відображень певних закономірностей, діаграм.

Шоста група включає завдання, що спрямовані на здійснення різних видів хімічного експерименту. Хімічний експеримент допомагає учням зв'язати теоретичні 
закономірності зі своїми власними спостереженнями i діями. Використання віртуального експерименту, відеофрагментів демонстрації дослідів, що особливо тривало протікають, дозволяє підвищити ефективність уроків.

Запропонована класифікація, хоча i не є всеосяжною, дозволяє викладачеві полегшити вибір необхідного класу моделей для вивчення окремого розділу з курсу хімії залежно від цілей або завдань зайняття, наприклад, моделей гібридизації атомних орбіталей або моделей молекул, або забруднення довкілля викидами промислових підприємств у вивченні хімічних технологічних процесів тощо.

Досить широкі можливості для використання у вивченні хімії у старших класах школи, технікумах i коледжах надають програмно-методичні комплекси «1С: Образовательная коллекция. Общая и неорганическая химия. 10-11 класс» та «1С: Образовательная коллекция. Органическая химия. 10-11 класс», які доступні в мережі Інтернет.

План вивчення хімічного виробництва, залежно від його характеру, попередньої підготовки учнів та інших обставин, може бути різноманітний. Проте теоретичні міркування і досвід роботи багатьох учителів показують, що вивчення основ технології хімічного виробництва доцільно проводити приблизно за таким планом.

1. Сировина i його підготовка до виробничого процесу (використовується колекція природних зразків і схема найважливіших апаратів, що застосовуються в процесі підготовки сировини до переробки).

2. Хімічні реакції, що лежать в основі виробництва, й умови протікання цих реакцій (бесіда із записом рівнянь).

3. Процес виробництва за окремими фазами (комп'ютерні презентації, відеофільми), і у зв'язку з цим: а) найосновніші, найбільш типові апарати; б) загальні принципи хімічного виробництва; в) засоби інтенсифікації виробництва; г) заходи із зменшення промислових викидів.

4. Продукт виробництва: повторення відомостей про його склад, найважливіші властивості; способах отримання і застосування (бесіда із застосуванням Інтернетресурсів).

Успішне вивчення хімічних виробництв вимагає попередньої підготовки не лише вчителя, але і учнів. До вивчення виробництва речовини необхідно приступати тільки після того, як учні засвоять: склад, властивості (фізичні і хімічні) і практичне значення цієї речовини, а також хімічні реакції отримання й умови, за яких ці реакції протікають.

Велику роль на уроках хімії мають демонстрації таблиць і схем технологічних процесів, моделей найбільш типових апаратів і установок цілих виробництв, а також демонстрації слайдів і фільмів, що ілюструють виробництва, які вивчаються. Осмисленню і закріпленню навчального матеріалу багато в чому сприяють самостійні заняття учнів, а також розв'язування завдань, особливо експериментальних i побудованих на виробничому матеріалі.

Необхідну інформацію навчального і науково-популярного характеру, яку слід використати для підготовки уроків 3 вивчення хімічних технологічних процесів i розв'язування експериментальних завдань, можна відшукати на таких сайтах:

- Абетка веб-пошуку для хіміків http://www.chemistry.bsu.by/abc;

- Аналітична хімія http://www.geocities.com/novedu;

- Органічна хімія http://formula44.narod.ru або http://cnit.ssau.ru/organics;

- Відкритий коледж - хімія http://www.chemistry.ru;

- Експериментальна хімія http://www.chemexperiment.narod.ru;

- Електронна бібліотека з хімії http://www.chemnet.ru/rus/elbibch.html;

- Репетитор 3 хімії http://chemistry.nm.ru;

- Інформація 3 хімії http://www.chemrar.ru; 
- Науково-популярний журнал «Химия и жизнь» http://www.hij.ru;

- урнал для школярів «Алхімік» http://www.alhimik.ru;

- Світ хімії http://www.chem.km.ru;

- Газета «Хімія» http://www.1 september.ru;

- Хімія для всіх http://www.informika.ru/text/database/chemy/START.html;

- Тестування 3 хімії http://kokch.kts.ru/cdo.

Суттєво активізує вивчення хімічних технологічних процесів розробка учнями комп'ютерних презентацій. Можна запропонувати учням таку модель створення тематичних презентацій.

1. Вивчення інформаційного блоку 3 виявленням ключових понять у їх взаємозв'язку.

2. Складання сценарію презентації, обговорення змісту і дизайну кожного слайду. У процесі обговорення учні ще раз повторюють навчальний матеріал, аналізують і систематизують його, представляють в короткій графічній формі.

3. Самостійна робота учнів із створення слайдів, пошуку ілюстрацій, схем, цікавих фактів, фотографій з використанням Інтернет-ресурсів.

4. Включення в презентацію слайдів зворотного зв'язку контролюючого характеру типу «перевір себе», «дай відповідь на запитання», «вибери правильну відповідь».

5. Оформлення слайд-шоу 3 використанням ефектів анімації, що дозволяє послідовно демонструвати навчальний матеріал у ході уроку.

Доцільно проводити у ході уроку обговорення представлених індивідуальних презентацій за обраною темою, що сприяє кращому засвоєнню навчального матеріалу.

Особливу увагу під час вивчення хімічних технологічних процесів слід звернути на питання екологічного характеру.

Диференціація хімічних виробництв відбивається як на характері продукції, що випускається, так і на викидах у довкілля, що має певне відношення до стану здоров'я населення. Основними несприятливо діючими чинниками $є$ хімічні речовини в різних фазових станах у поєднанні 3 фізичними, механічними, гігієнічними і іншими особливостями середовища. Довкілля може забруднюватися хімічними речовинами в твердому, рідкому, газо- і пароподібному станах. Повітря виробничих приміщень i довкілля можуть забруднюватися також аерозолями з твердою і рідкою дисперсними фазами, різними газами, парами, пилом і твердими відходами.

Залежно від технологічного процесу на основі вивчення характеру і причин забруднення атмосферного повітря підприємствами хімічної промисловості зазвичай виділяють такі групи забруднень:

1) неповний вихід продукції, обумовлений особливостями протікання реакцій, що виключають використання початкових продуктів, або в результаті втрат кінцевого продукту;

2) викиди в атмосферу домішок і забруднень, що містяться в сировині;

3) втрата низки речовин, що використовуються у виробничих процесах;

4) виділення пахучих речовин і продуктів окислення, що потрапляють в повітря в результаті хімічних реакцій, нагрівання або сушки.

Певні можливості для оцінки впливу на стан довкілля надає порівняння схожих технологічних процесів, наприклад, між перегонкою і крекінгом нафти, отримання сталі із чугуна у мартенівських або електричних печах.

Вивчення технологічних процесів у курсі хімії середньої школи створює нові досить широкі можливості для інтеграції знань з різних предметів природничого циклу. Головна ідея інтеграції знань у навчально-виховному процесі полягає в тому, щоб об'єднати навчальний матеріал у певну цілісну систему, визначити взаємозалежності 
між навчальними дисциплінами, розкрити міжпредметні зв'язки. Виокремлюють три рівні дидактичної інтеграції різних навчальних дисциплін:

I рівень - міждисциплінарна інтеграція в навчальному процесі. Цей рівень можна виразити поняттям «міжпредметний зв' язок»;

II рівень - це синтез взаємопов'язаних наук на основі однієї з них (базової). Кожна наука зберігає власний предмет, свої концептуальні основи, тобто має свій науковий статус;

III рівень - так званий рівень доцільності, що завершується формуванням нової навчальної дисципліни, має інтегрований характер і свій предмет вивчення [2, с. 25].

Інтеграція може бути різноплановою, оскільки поєднання окремих частин у гармонійне ціле сприяє реалізації багатьох принципів освіти. Методологічні засади інтеграції знань 3 різних предметів природничого циклу під час вивчення технологічних процесів у курсі хімії ще потребують свого окремого дослідження і впровадження у педагогічну практику.

\section{4. ВИСНОВКИ ТА ПЕРСПЕКТИВИ ПОДАЛЬШИХ ДОСЛІДЖЕНЬ}

Використання засобів IКТ на уроках хімії дозволяє досягти якісно нового рівня реалізації принципу наочності. 3 методичної точки зору комп'ютерне моделювання під час вивчення хімії доцільно використовувати, коли необхідно вивчати процеси і явища, які 3 допомогою хімічних експериментів в умовах шкільної лабораторії вивчити неможливо [7].

Перевага уроків хімії на основі використання засобів ІКТ полягає в тому, що з їх допомогою можна розв'язати низку актуальних проблем, які стоять перед школою. До них, передусім, відносяться:

1. Застосування комп'ютерних технологій у вивченні хімії активно сприяє підвищенню інтересу учнів до предмета, оскільки є ефективним методом вирішення проблеми мотивації в сучасній освіті.

2. Підвищення якості навчально-виховного процесу, приведення його до сучасного рівня науково-технічного прогресу.

3. Реальна підготовка учнів до життя і роботи в інформаційному суспільстві, до праці в сучасному автоматизованому процесі, до професійної мобільності.

4. Надання допомоги учителеві в застосуванні різних форм проведення заняття, контролю знань, організації ефективного зворотного зв’язку.

5. Створення комфортної психологічної ситуації в процесі навчання, за якої виключаються багато конфліктів у системі «учень - учитель».

6. Надання допомоги у розв'язанні низки завдань розвитку особистості, формування ㄲï компетентності, здатності до саморегуляції, творчості, розвитку інтелекту.

7. Активізація пізнавальної діяльності учнів у процесі навчання хімії, що дозволяє вийти на більш високий рівень сприйняття і засвоєння вивченого матеріалу, його застосування в житті.

Педагогічною наукою і практикою доведено, що робота із засобами IКТ на уроках i у позаурочний час ефективно забезпечує реалізацію індивідуального підходу до навчання, що дозволяє вибудовувати персональну навчальну траєкторію практично для кожного учня. 


\title{
СПИСОК ВИКОРИСТАНИХ ДЖЕРЕЛ
}

1. Бондаренко А. А. Технология химической промышленности: учебное пособие. - К. : Вища школа, 1982. - 152 с.

2. Гриценко Н. Інтеграція предметів природничо-математичного циклу в умовах профільного навчання / Н. Гриценко. — К. : Шкільний світ. Завуч. — 2007. — № 21 (315). — С. 25-26.

3. Мельник О. В. Профорієнтаційна робота зі школярами в умовах профільного навчання : [науковометодичний посібник для викладачів] / О. В. Мельник, І. Л. Уличний. - К. : Педагогічна думка, 2008. - $128 \mathrm{c}$.

4. Науменко О. М. Окремі аспекти застосування Інтернет-орієнтованих педагогічних технологій навчання хімії [Електронний ресурс] / О. М. Науменко // Інформаційні технології і засоби навчання: електронне наукове фахове видання. - К. : ІІТЗН НАПН України. — 2012. — Том 30, № 4. - Режим доступу : http://www.jornal.iitta.gov.ua/index.php/itlt/article/view/570.

5. Науменко О. М. Інтернет-ресурси і підвищення якості шкільної хімічної освіти: [Електронний ресурс] / О. М. Науменко // Інформаційні технології і засоби навчання: електронне наукове фахове видання. - К. : ІІТЗН НАПН України, 2013. - Том 34, № 2. - С. 56-63. - Режим доступу : http://www.jornal.iitta.gov.ua/index.php/itlt/article/view/808.

6. Науменко О. М. Методика пошуку Інтернет-ресурсів для демонстрації технологічних процесів під час вивчення хімії [Електронний ресурс] / О. М. Науменко // Інформаційні технології і засоби навчання: електронне наукове фахове видання. - К. : ІІТЗН НАПН України, 2014. — Том 39, № 1. — C. 141-148. — Режим доступу : http://journal.iitta.gov.ua/index.php/itlt/article/view/965.

7. Новые педагогические и информационные технологии в системе образования : [учеб. пособие для студ. пед. вузов и системы повыш. квалиф. пед. кадров] / [Полат Е. С., Бухоркина М. Ю., Моисеева М. В., Петров А.Е. ; под ред. Е. С. Полат]. — М. : Издательский центр «Академия», 2002. $-272 \mathrm{c}$.

8. Хімія 10-12 класи: Програми для профільного навчання учнів загальноосвітніх навчальних закладів : рівень стандарту, академічний рівень, профільний рівень та поглиблене вивчення. / Упорядники С. С. Фіцайло, О. А. Дубовик. — Тернопіль : Мандрівець, 2010. — 248 с.

9. Сторіжко В. Ю. Основні положення Концепції створення та впровадження в навчальний процес сучасних засобів навчання 3 природничо-математичних i технологічних дисциплін / Сторіжко В. Ю., Биков В. Ю., Жук Ю. О. // Фізика та астрономія в школі. — 2006. — № 2. — C. 2-8.

\section{МЕТОДИКА ПОДГОТОВКИ ЗАНЯТИЙ ПО ИЗУЧЕНИЮ ХИМИЧЕСКИХ ТЕХНОЛОГИЧЕСКИХ ПРОЦЕССОВ С ИСПОЛЬЗОВАНИЕМ ИНТЕРНЕТ- РЕСУРСОВ}

\author{
Науменко Ольга Михайловна, \\ младший научный сотрудник отдела лабораторных комплексов средств обучения \\ Институт информационных технологий и средств обучения НАПН Украины, г. Киев, Украина \\ o.naumenko@iitta.gov.ua
}

\begin{abstract}
Аннотация. Рассматриваются отдельные вопросы методики подготовки и проведения занятий с применением Интернет-ресурсов для демонстрации технологических процессов при изучении химии в старшей школе. Изучение научных основ современного производства, в том числе и химических технологических процессов, является важным средством формирования у учеников необходимых жизненных компетенций. Процесс изучения химических производств связывает теорию с практикой, конкретизирует и углубляет знание теоретических основ химии, а также способствует профориентации ученической молодежи. Значительное внимание уделено советам для учителей относительно методики использования средств информационно-коммуникационных технологий при подготовке и проведении практических и лабораторных занятий, других форм учебно-поисковой деятельности учеников.
\end{abstract}

Ключевые слова: Интернет; информатизация образования; химия; изучение химии; технологические процессы. 


\title{
METHODOLOGY OF PREPARATION OF LESSONS FOR STUDY OF CHEMICAL PROCESSES USING INTERNET RESOURCES
}

\author{
Olga M. Naumenko \\ junior researcher of the Department of laboratory complexes and learning tools \\ Institute of Information Technologies and Learning Tools of the NAPS of Ukraine, Kyiv, Ukraine \\ o.naumenko@iitta.gov.ua
}

\begin{abstract}
In the article there are considered some questions of methodology of preparation and giving classes using Internet-resources for demonstration of technological processes while studying chemistry at senior school. Study of scientific bases of modern production, including chemical technological processes, is the important means of forming students' necessary vital competences. The process of study of chemical productions binds a theory to practice, specifies and deepens knowledge of theoretical bases of chemistry, and also assists the vocational orientation of student's young people. Considerable attention is spared to advices for teachers in relation to methodology of the use of facilities of information and communication technologies at preparation and realization of practical and laboratory classes, other forms of educationalsearching activity of students.
\end{abstract}

Keywords: Internet; informatization of education; chemistry; study of chemistry; technological processes.

\section{REFERENCES (TRANSLATED AND TRANSLITERATED)}

1. Bondarenko A. A. Technology of chemical industry: [train aid] — K. : Vyshcha shkola, 1982. — $152 \mathrm{~s}$. (in Russian).

2. Hrytsenko N. Integration of the articles of naturally-mathematical cycle is in the conditions of profile studies / N. Hrytsenko. — K., Shkilnyi svit. Zavuch. - 2007. — \# 21 (315). — S. 25-26 (in Ukrainian).

3. Melnyk O. Professional orientation of students in terms of profile education: [R Manual for Teachers] / O. V. Melnyk, I. L. Ulychnyi. — K. : Pedahohichna dumka, 2008. - 128 s. (in Ukrainian).

4. Naumenko O. M. Separate aspects of application of the internet-oriented pedagogical Technologies of studies of chemistry [online] / O. M. Naumenko // Informatsiini tekhnolohii i zasoby navchannia : elektronne naukove fakhove vydannia. - Kyiv : IITZN NAPN Ukrainy, 2012. - Tom 30, \# 4. Available from : http://www.jornal.iitta.gov.ua/index.php/itlt/article/view/570 (in Ukrainian).

5. Naumenko O. M. Resources of the Internet and upgrading of school chemical education [online] / O. M. Naumenko // Informatsiini tekhnolohii i zasoby navchannia: elektronne naukove fakhove vydannia. - Kyiv, IITZN NAPN Ukrainy. - 2013. - Tom 34, \# 2. - S. 56-63. - Available from : http://www.jornal.iitta.gov.ua/index.php/itlt/article/view/808 (in Ukrainian).

6. Naumenko O. M. Methodology of search of Resources of the Internet is for demonstration of technological processes during the study of chemistry [online] / O. M. Naumenko // Informatsiini tekhnolohii i zasoby navchannia: elektronne naukove fakhove vydannia. - Kyiv : IITZN NAPN Ukrainy, 2014. - Tom 39, \# 1. - S. 141-148. — Available from : http://www.jornal.iitta.gov.ua/index.php/itlt/article/view/965 (in Ukrainian).

7. Polat E. S., Bukhorkyna M. Yu., Moyseeva M. V., Petrov A. E. New teaching and information technology in the education system [Proc. allowance for stud. ped. universities and the system improved. Qualifying to. ped. frames] / Pod red. E.S. Polat. — M. : Yzdatelskyi tsentr «Akademyia», 2002. — 272 s. (in Russian).

8. Chemistry classes 10-12: Applications for profile training students of secondary schools: the level of the standard, academic level, profile and level of in-depth study. /Uporiadnyky S. S. Fitsailo, O. A. Dubovyk. — Ternopil : Mandrivets, 2010. — 248 s. (in Ukrainian).

9. Storizhko V. Yu., Bikov V. Yu., Zhuk Yu. O. Main principles of the Concept of creation of modern means of education in natural-mathematical and technological subjects and their introduction in studying process // Fizika ta astronomiya v shkoli. — 2006. — № 2. — S. 2-8 (in Ukrainian). 